\title{
Olfactory Bulb Short Axon Cell Release of GABA and Dopamine Produces a Temporally Biphasic Inhibition-Excitation Response in External Tufted Cells
}

\author{
Shaolin Liu, Celine Plachez, Zuoyi Shao, Adam Puche, and Michael T. Shipley \\ Department of Anatomy and Neurobiology, Program in Neuroscience, University of Maryland School of Medicine, Baltimore, Maryland 20201
}

Evidence for coexpression of two or more classic neurotransmitters in neurons has increased, but less is known about cotransmission. Ventral tegmental area (VTA) neurons corelease dopamine (DA), the excitatory transmitter glutamate, and the inhibitory transmitter GABA onto target cells in the striatum. Olfactory bulb (OB) short axon cells (SACs) form interglomerular connections and coexpress markers for DA and GABA. Using an optogenetic approach, we provide evidence that mouse OB SACs release both GABA and DA onto external tufted cells (ETCs) in other glomeruli. Optical activation of channelrhodopsin specifically expressed in DAergic SACs produced a $\mathrm{GABA}_{\mathrm{A}}$ receptor-mediated monosynaptic inhibitory response, followed by $\mathrm{DA}-\mathrm{D}_{1}$-like receptor-mediated excitatory response in ETCs. The $\mathrm{GABA}_{\mathrm{A}}$ receptor-mediated hyperpolarization activates $I_{\mathrm{h}}$ current in ETCs; synaptically released DA increases $I_{\mathrm{h}}$, which enhances postinhibitory rebound spiking. Thus, the opposing actions of synaptically released GABA and DA are functionally integrated by $I_{\mathrm{h}}$ to generate an inhibition-to-excitation "switch" in ETCs. Consistent with the established role of $I_{\mathrm{h}}$ in ETC burst firing, we show that endogenous DA release increases ETC spontaneous bursting frequency. ETCs transmit sensory signals to mitral/tufted output neurons and drive intraglomerular inhibition to shape glomerulus output to downstream olfactory networks. GABA and DA cotransmission from SACs to ETCs may play a key role in regulating output coding across the glomerular array.

\section{Introduction}

Dopamine (DA) plays important roles in motor behaviors, Parkinson's disease, reward reinforcement, addiction, working memory, and schizophrenia (Greengard, 2001; Björklund and Dunnett, 2007; Iversen and Iversen, 2007; Beaulieu and Gainetdinov, 2011). This modulatory neurotransmitter is distributed in nine major neuron groups, including the substantia nigra, ventral tegmental area (VTA), and olfactory bulb (OB) (Dahlstroem and Fuxe, 1964; Björklund and Dunnett, 2007).

DA influences odor discrimination (Kruzich and Grandy, 2004; Yue et al., 2004; Pavlis et al., 2006; Tillerson et al., 2006; Wei et al., 2006; Doty, 2012). $\mathrm{D}_{2}$-like receptors are predominantly present in olfactory nerve $(\mathrm{ON})$ terminals and glomerular layer (GL); $\mathrm{D}_{1}$-like receptors are widely distributed throughout $\mathrm{OB}$, except for the olfactory nerve layer (ONL) (Nickell et al., 1991; Coronas et al., 1997; Koster et al., 1999; Gutièrrez-Mecinas et al., 2005). DA presynaptically inhibits the first synapse of the olfactory system by reducing glutamate release from ON terminals via

\footnotetext{
Received July 27, 2012; revised Dec. 13, 2012; accepted Dec. 16, 2012.

Author contributions: S.L., A.P., and M.T.S. designed research; S.L., C.P., and Z.S. performed research; S.L. analyzed data; S.L. and M.T.S. wrote the paper.

This work was supported by National Institutes of Health Grants DC005676 and DC010915. We thank Dr. Renee Cockerham for assistance with animal preparation.

Correspondence should be addressed to either Shaolin Liu or Michael T. Shipley, Department of Anatomy and Neurobiology, University of Maryland School of Medicine, 20 Penn Street, Baltimore, MD 20201; E-mail: sliu003@umaryland.edu, mshipley@umaryland.edu.

DOI:10.1523/JNEUROSCI.3607-12.2013

Copyright $\odot 2013$ the authors $\quad 0270-6474 / 13 / 332916-11 \$ 15.00 / 0$
}

$\mathrm{D}_{2}$-like receptors (Wachowiak and Cohen, 1999; Berkowicz and Trombley, 2000; Ennis et al., 2001).

In the $\mathrm{OB}$ tyrosine hydroxylase $(\mathrm{TH})$, the rate-limiting enzyme in DA biosynthesis, is localized to neurons predominantly within the GL (Hökfelt et al., 1975; Baker et al., 1983; Kosaka et al., 1985; Gall et al., 1987; McLean and Shipley, 1988; Goheen Robillard et al., 1997). The vast majority of juxtaglomerular cells (JGCs), a heterogeneous population of interneurons surrounding each glomerulus, are GABAergic (Parrish-Aungst et al., 2007; Kiyokage et al., 2010). In contrast to VTA TH-expressing $\left(\mathrm{TH}^{+}\right)$ neurons that corelease DA, glutamate, and GABA (Chuhma et al., 2004; Hnasko et al., 2010; Stuber et al., 2010; Tecuapetla et al., 2010; Yamaguchi et al., 2011; Tritsch et al., 2012), TH in JGCs colocalizes with GABA and glutamic acid decarboxylase (GAD), the rate-limiting enzyme for GABA biosynthesis (Hökfelt et al., 1975; Baker et al., 1983; Kosaka et al., 1985; Gall et al., 1987; Goheen Robillard et al., 1997; Kosaka and Kosaka, 2008; Kiyokage et al., 2010). This suggests that DA and GABA are cotransmitters in OB. Consistent with this idea, GABA mediates self-inhibition in $\mathrm{TH}^{+}$JGCs (Maher and Westbrook, 2008).

JGCs coexpressing markers for DA and GABA are short axon cells (SACs), which send extensive processes to multiple neighboring glomeruli, forming the interglomerular circuit (IGC) (Kosaka and Kosaka, 2008; Kiyokage et al., 2010). These observations raise several questions. (1) Do SACs cotransmit GABA and DA? (2) What are the effects of GABA-DA cotransmission on postsynaptic targets? (3) What is the impact of cotransmission at the circuit level? To address these questions, we investigated synaptic transmission from SACs to external tufted cells (ETCs), a 
key glomerular neuron that gates the glomerular output by transferring $\mathrm{ON}$ input to their postsynaptic targets, including the majority of GABAergic periglomerular cells (PGC), GABA/DAergic SACs (Hayar et al., 2004a; Shao et al., 2009; Kiyokage et al., 2010), and the main output neurons of the OB-mitral/tufted cells (M/ TCs) (De Saint Jan et al., 2009; Gire et al., 2012). To ensure specific activation of SACs, we used viral expression of credependent channelrhodopsin $2(\mathrm{ChR} 2)$ in a line of transgenic mice in which the $\mathrm{TH}$ promoter drives cre. Our previous study showed that all $\mathrm{TH}^{+}$SACs coexpress GAD-67 (Kiyokage et al., 2010); thus, this optogenetic approach provided us a precise tool to investigate GABA-DA cotransmission through selective activation of SACs.

\section{Materials and Methods}

Animals. Wild-type male mice (C57BL/6J) and transgenic TH-Cre mice [B6.Cg-Tg(TH-Cre) $1 \mathrm{Tmd} / \mathrm{J}]$ were obtained from Charles River and The Jackson Laboratory, respectively. A colony of transgenic animals was maintained by breeding heterozygous male $\mathrm{TH}-\mathrm{Cre}$ mice with wild-type C57BL/6J female mice. Animals were maintained with a standard $12 \mathrm{~h}$ light/dark cycle and given food and water ad libitum. All experimental procedures were performed in accordance with protocols submitted to and approved by the University of Maryland Institutional Animal Care and Use Committee.

ChR2 expression. Adeno-associated virus serotype 9 (AAV2.9) carrying fusion genes for ChR2 and enhanced yellow (EYFP) fluorescent protein or mCherry (Tsai et al., 2009) (University of Pennsylvania Vector Core, Philadelphia, PA) were injected into the GL of the medial side of each OB between postnatal weeks 4 and 6. Under deep anesthesia, skull was exposed, and a small hole was drilled over each $\mathrm{OB}$ with typical coordinates at $3.95 \mathrm{~mm}$ from bregma and $0.2 \mathrm{~mm}$ from midline. AAV2.9 was injected into three points within the GL of the medial side of each bulb (depth of $2.0,1.5$, and $1.0 \mathrm{~mm}$ ) at a rate of $0.1 \mu \mathrm{l} / \mathrm{min}$ for $5 \mathrm{~min}$. After $2-3$ weeks for ChR2-EYFP fluorescent protein expression, acute OB slices were prepared for experiments.

Slice preparation. Acute OB slices from 6- to 8-week-old male mice were prepared as described previously (Liu and Shipley, 2008a). Briefly, horizontal slices $(350 \mu \mathrm{m})$ were cut with a VT1200s Vibratome in an ice-cold and oxygenated $\left(95 \% \mathrm{O}_{2}-5 \% \mathrm{CO}_{2}\right)$ sucrose-based artificial CSF (ACSF) containing the following (in $\mathrm{mM}$ ): 204.5 sucrose, $3 \mathrm{KCl}, 4.5 \mathrm{~N}, \mathrm{~N}$ bishydroxyethyl-2-aminoethane-sufonic acid (BES), $2.6 \mathrm{MgSO}_{4}, 0.5$ $\mathrm{CaCl}_{2}, 26 \mathrm{NaHCO}_{3}$, and 10 glucose. After 30 min incubation in normal ACSF at $30^{\circ} \mathrm{C}$, slices were then transferred to ACSF at room temperature until they were used for experiments. Normal ACSF was continuously bubbled with $95 \% \mathrm{O}_{2}-5 \% \mathrm{CO}_{2}$ and had the following composition (in $\mathrm{mm}$ ): $124 \mathrm{NaCl}, 3 \mathrm{KCl}, 4.5 \mathrm{BES}, 1.3 \mathrm{MgSO}_{4}, 1.3 \mathrm{CaCl}_{2}, 26 \mathrm{NaHCO}_{3}$, and 10 glucose. During experiments, slices were perfused at $3 \mathrm{ml} / \mathrm{min}$ with ACSF equilibrated with $95 \% \mathrm{O}_{2}-5 \% \mathrm{CO}_{2}$ and warmed to $30^{\circ} \mathrm{C}$.

Electrophysiology. Whole-cell patch-clamp or cell-attached recordings were made from OB TH-EYFP-labeled SACs and ETCs visualized using BX50WI (Olympus) fixed-stage upright microscope equipped with nearinfrared differential interference contrast (DIC) optics. SACs were identified by their expression of EYFP. ETCs were identified as described previously (Liu et al., 2012). Briefly, they are identified for experiments based on the following three criteria: (1) spontaneous intrinsic burst firing that persists even when fast synaptic transmitter (AMPA, NMDA, and $\mathrm{GABA}_{\mathrm{A}}$ ) receptors are blocked; (2) "pear"-shaped cell body located in the deep half of the GL when viewed in infrared DIC optics; and (3) an apical dendrite with extensively ramified tuft confined to the glomerulus and absence of lateral dendrites in the external plexiform layer.

Current or voltage signals were recorded with a MultiClamp 700B amplifier (Molecular Devices), low-pass filtered at $4 \mathrm{kHz}$, and sampled at $10 \mathrm{kHz}$ with a DIGIDATA 1322A 16-bit analog-to-digital converter (Molecular Devices) using Clampex 9.2 (Molecular Devices). Patch recording electrodes were pulled from standard-wall glass capillary tubes without filament (Sutter Instruments). Patch pipettes (4-7 M $\Omega$ ) for whole-cell recording contained the following (in $\mathrm{mm}$ ): $115 \mathrm{~K}$-gluconate,
5.0 EGTA, 0.63 $\mathrm{CaCl}_{2}$, $5.5 \mathrm{Mg}-\mathrm{Cl}_{2}, 10$ HEPES, $3 \mathrm{Na}_{2}$-ATP, $0.3 \mathrm{Na}_{3}$-GTP, and 14 Tris-phosphocreatine, $\mathrm{pH} 7.3$ (285-295 mOsm). The liquid junction potential $(11-13 \mathrm{mV})$ was not corrected. Access resistance was typically $<30 \mathrm{M} \Omega$ and not compensated.

Electrical and optical stimulation. Electrical stimulation was delivered by bipolar glass electrodes made from theta borosilicate tubes (Sutter Instruments). The isolated and constant-current stimulation pulses (100 $\mu \mathrm{s})$ were triggered by a PG4000A digital stimulator (Cygnus Technology). Optical stimuli were delivered from a $25 \mu \mathrm{m}$ multimode optical fiber ( 0.1 numerical aperture, $\sim 7^{\circ}$ beam spread; ThorLabs) coupled to a $150 \mathrm{~mW}, 473 \mathrm{~nm}$, diode-pumped, solid-state laser (LWBL473083272; Made-in-China) and gated with a Uniblitz shutter. Optical power delivered at the fiber tip was calibrated with a PM20A power meter (ThorLabs). Onset and duration of optical stimulation was measured during every experiment by splitting $1 \%$ of the laser beam out to a high speed ( 30 ns rise time) silicon photosensor (model 818-BB; Newport) and recorded by the same MultiClamp 700B amplifier as the patch electrode.

Data analyses. Data were analyzed with Clampfit 9.2 (Molecular Devices), SigmaPlot 9.0 (Systat Software), NeuroExplorer (Nex Technologies), and Origin 8.5 (OriginLab). All data were presented as mean \pm SE. Statistical analyses were performed with NCSS 8.0 (NCSS Software). Statistical significance for group comparisons of repeated measures from the same neurons were determined by either paired Student's $t$ tests (see Figs. $1 C, 4 E$ ) or one-way repeated-measures ANOVA with Bonferroni's test (see Figs. $2 H, 3 F, G, 5 E, 6 E-H$ ). Statistical significance of nonrepeated measures from different neurons were calculated with one-way ANOVA with Bonferroni's multiple-comparison test (see Figs. 4C, $G$, $5 F, G$ ) or nonpaired Student's $t$ test (see Fig. $4 C$, DHX and SCH + DHX).

Immunohistochemistry. OB slices (350 $\mu$ m thickness) were fixed in $4 \%$ paraformaldehyde for $24 \mathrm{~h}$ after physiological recordings. Then they were embedded in $10 \%$ gelatin in $1 \times$ PBS and recut using a vibratome (Leica) at $40 \mu \mathrm{m}$. Immunohistochemistry was performed at room temperature on free-floating sections. After several washes, sections were incubated for $30 \mathrm{~min}$ in $2 \%$ bovine serum albumin in TBST $(0.1 \mathrm{M}$ Tris, $\mathrm{pH} 7.4,0.9 \%$ saline, and $0.3 \%$ Triton X-100) and then incubated overnight with a mouse anti-TH antibody (1:10,000; 22941; Immunostar). Sections were rinsed and incubated in anti-mouse Cy5-conjugated secondary antibodies (1:1000; Jackson ImmunoResearch) for $2 \mathrm{~h}$ at room temperature. Biocytin was detected using an anti-streptavidin Cy3conjugated antibody (1:1000; Jackson ImmunoResearch) for $2 \mathrm{~h}$ at room temperature. EYFP was detected by the intrinsic fluorescence of the molecule. Sections were washed and mounted on gelatin-coated slides and coverslipped with a 1,4-diazabicyclo-[2.2.2] octane-based anti-fade mounting media. Digital microscopy images were captured using a FluoView500 confocal microscope (Olympus) and assembled using CorelDraw X4 (Corel).

Drugs and chemicals. DL-2-Amino-5-phosphonovaleric acid (APV; 50 $\mu \mathrm{M}$ ), 2,3-dioxo-6-nitro-1,2,3,4-tetrahydrobenzo[f] quinoxaline-7-sulfonamide disodium salt (NBQX disodium salt; $10 \mu \mathrm{M}$ ), gabazine (GBZ; SR95531; $10 \mu \mathrm{M}$ ), 4-ethylphenylamino-1,2-dimethyl-6-methylaminopyrimidinium chloride (ZD7288; $20 \mu \mathrm{M})$, ( \pm )-trans-10,11-dihydroxy5,6,6a,7,8,12b-hexahydrobenzo[a]phenanthridine hydrochloride (DHX hydrochloride; $10 \mu \mathrm{M}$ ), octahydro-12-(hydroxymethyl)-2-imino-5,9:7,10adimethano-10a $H$ - $[1,3]$ dioxocino[6,5-d]pyrimidine-4,7,10,11,12-pentol citrate (TTX citrate; $1 \mu \mathrm{M}),(6 \mathrm{aS}$-trans)-11-chloro-6,6a,7,8,9,13b-hexahydro-7-methyl-5H-benzo[d]naphth[2,1-b]azepin-12-ol hydrobromide (SCH39166 hydrobromide; $10 \mu \mathrm{M}$ ), and (2S)-3-[[(1S)-1-(3,4-dichlorophenyl)ethyl]amino-2-hydro xypropyl](phenylmethyl)phosphinic acid (CGP55845; $10 \mu \mathrm{M}$ ) were purchased from Tocris Cookson. 2-(3,4-Dihydroxyphenyl)ethylamine hydrochloride, 3,4-dihydroxyphenethylamine hydrochloride, 3-hydroxytyramine hydrochloride, 4-(2-aminoethyl)-1,2benzenediol hydrochloride (dopamine hydrochloride; $20 \mu \mathrm{M}$ ), (S)-5aminosulfonyl- $N$-[(1-ethyl-2-pyrrolidinyl)methyl]-2-methoxybenzamide [(S)-(-)-sulpiride; $20 \mu \mathrm{M})$, and all other chemicals were purchased from Sigma-Aldrich. All drugs were bath applied by diluting in ACSF at the above indicated doses unless otherwise stated. 
A

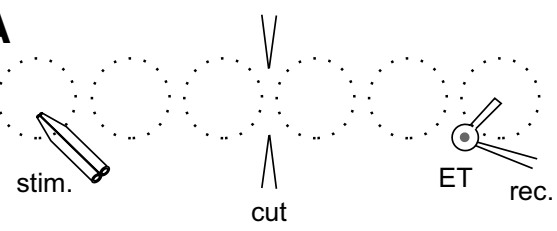

B
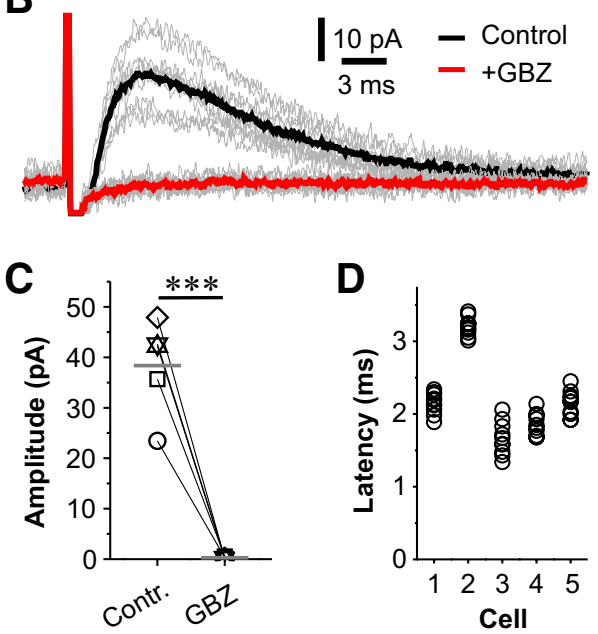

Figure 1. Stimulation of the IGC produces an inhibitory monosynaptic response in ETCs. A, Schematic diagram showing the experimental design. $\boldsymbol{B}$, Voltage-clamp recording traces showing the synaptic responses in ETCs (held at $0 \mathrm{mV}$ ) to interglomerular stimulation. Thick traces represent the average. C, Population data from five ETC s showing that the IPSC amplitude in the absence (control) or presence (10 $\mu \mathrm{M})$ of GBZ. ${ }^{* * *} p<0.001(n=5$ cells, paired Student's $t$ test). $\boldsymbol{D}$, Pooled data from five ETCs showing the IPSC latencies and their variation.

\section{Results}

\section{SACs monosynaptically inhibit ETCs}

SACs coexpress TH and GAD-67, a rate-limiting enzyme for GABA biosynthesis, suggesting that their synapses release both GABA and DA (Kiyokage et al., 2010). SACs have extensive processes that innervate many neighboring glomeruli, thus forming the IGC (Aungst et al., 2003; Kosaka and Kosaka, 2008; Kiyokage et al., 2010). The interglomerular postsynaptic targets of SACs are not known. One potential target is the ETC, a glomerular neuron that receives direct ON synapses and provides monosynaptic excitatory input to M/TCs and the majority of local PGCs and SACs. ETCs thus play a key role in both excitatory and inhibitory glomerular network operations (Hayar et al., 2004a; De Saint Jan et al., 2009; Gire and Schoppa, 2009; Shao et al., 2009; Kiyokage et al., 2010; Gire et al., 2012).

If SACs release GABA onto ETCs, then interglomerular stimulation should produce GABA-mediated monosynaptic responses in ETCs. To stimulate interglomerular axons in isolation from other intrabulbar connections, we prepared slices with two microsurgical cuts: one through the ONL and a second through all layers deep to the glomeruli leaving only interglomerular connections intact (Aungst et al., 2003). ETCs rostral to the cuts were voltage clamped at $0 \mathrm{mV}$ to optimize detection of IPSCs while electrical stimulation was delivered to the GL caudal to the cuts (Fig. 1A). To further enhance detection of IPSCs and to minimize other potential circuit effects recruited by glomerular stimulation, NBQX $(10 \mu \mathrm{M})$ and APV $(50 \mu \mathrm{M})$ were present throughout the experiments. As predicted, interglomerular stimulation evoked an outward current that was abolished by GBZ (10 $\mu \mathrm{M}$; Fig. $1 B$ ), indicating mediation by $\mathrm{GABA}_{\mathrm{A}}$ receptors. The peak amplitude of this response was $38.4 \pm 4.2 \mathrm{pA}(n=5)$ in control and $0.3 \pm 0.1 \mathrm{pA}(n=5, p<0.001)$ in the presence of GBZ (Fig. $1 C)$. The short response latency $(2.2 \pm 0.3 \mathrm{~ms}, n=5)$ and lowlatency jitter (165 $\pm 17 \mu \mathrm{s}, n=5)$ are consistent with monosynaptic GABAergic interglomerular transmission from SACs to ETCs (Fig. 1D).

With electrical stimulation, it is impossible to rule out that other unidentified glomerular neurons, in addition to SACs, contribute interglomerular monosynaptic input to ETCs. To selectively activate DA-GABAergic SACs, we devised a ChR2-based optogenetic strategy in which a cre-inducible AAV2.9 vector carrying an inverted double-floxed ChR2-EYFP fusion construct was microinjected into the GL of TH-Cre mice. This consistently yielded ChR2-EYFP expression that was restricted to the GL (Fig. $2 A)$ in which DA neurons are predominantly distributed (Dahlstroem and Fuxe, 1964; Kosaka et al., 1985; Gall et al., 1987; Goheen Robillard et al., 1997; Björklund and Dunnett, 2007; Parrish-Aungst et al., 2007; Kiyokage et al., 2010). Immunohistochemical staining of $\mathrm{TH}$ protein (Fig. $2 B, C$ ) confirmed that $90.8 \pm 0.6 \%$ ( $n=108$ cells from 3 mice) of ChR $2^{+}$glomerular neurons were $\mathrm{TH}^{+}$. The remaining $\sim 10 \%$ may represent immature SACs that express the $\mathrm{TH}$ gene and drive ChR2 but do not yet express detectable levels of TH protein (Baker et al., 2001; SainoSaito et al., 2004).

To characterize ChR2 channels and the efficacy of light activation in SACs, we made whole-cell patch-clamp recordings from ChR2 ${ }^{+}$cells. Post hoc colocalization of ChR2-EYFP, TH, and biocytin loaded into the recorded cells via the patch pipette confirmed that all recorded neurons were ChR2 ${ }^{+}$DAergic SACs (Fig. $2 C$ ). $\mathrm{ChR} 2{ }^{+}$glomerular neurons exhibited typical electrophysiological properties of SACs with a mean membrane potential of $-69.5 \pm 2.1 \mathrm{mV}$ and a mean resistance of $639.3 \pm 9.7 \mathrm{M} \Omega$ ( $n=7$ cells), consistent with previously reported values for SACs in wild-type animals (Hayar et al., 2004a). This indicates that ChR2 expression does not influence the basic electrical properties of SACs. Next we investigated the responses of $\mathrm{ChR} 2{ }^{+}$SACs to $473 \mathrm{~nm}$ laser light activation. To minimize exposure to laser light, which might cause phototoxicity (Hopt and Neher, 2001), exposure was limited to $3 \mathrm{~ms}$ in all the experiments. All tested cells showed a light-intensity-dependent inward current (Fig. 2D, $n=$ 5 cells) when held at $-70 \mathrm{mV}$ in the presence of TTX (1 $\mu \mathrm{M})$ to eliminate action currents and circuit influences. The peak amplitude of this light-evoked current from five cells was $69.8 \pm 18.5$ $\mathrm{pA}$ at $7 \mu \mathrm{W}, 510.7 \pm 114.2 \mathrm{pA}$ at $520 \mu \mathrm{W}$, and $1213.9 \pm 175.8 \mathrm{pA}$ at $3.75 \mathrm{~mW}$ of laser light (Fig. $2 D$ ). The insensitivity of the current to TTX and fast synaptic transmission blockers (10 $\mu \mathrm{M}$ NBQX, 50 $\mu \mathrm{M}$ APV, and $10 \mu \mathrm{M}$ GBZ) confirmed that it was attributable to direct activation of ChR2 in SACs.

In current clamp, laser light exposure evoked action potentials in $\mathrm{ChR2}{ }^{+}$SACs. The number of spikes increased (Fig. $2 E$ ) from $1.7 \pm 0.7,4.6 \pm 1.4$, to $5.6 \pm 1.4$ whereas the latency of the first spike decreased from $3.8 \pm 0.5,1.3 \pm 0.3$, to $0.9 \pm 0.2 \mathrm{~ms}$ with incremental light intensity (Fig. $2 F$ ) from $7 \mu \mathrm{W}, 520 \mu \mathrm{W}$, to 3.75 $\mathrm{mW}$, respectively ( $n=5$ cells). Although $3.75 \mathrm{~mW}$ yielded the maximum number of spikes from SACs, repetitive exposure to light of this intensity could potentially cause phototoxicity (Hopt and Neher, 2001). Thus, in all subsequent experiments, we used $520 \mu \mathrm{W}$, which was the lowest light intensity yielding robust near-maximal SAC spiking ( $\sim 85 \%$ of maximum; Fig. $2 E$ ).

Next we investigated the SAC $\rightarrow$ ETC synaptic connection. ETCs were voltage clamped at $-55 \mathrm{mV}$, and optical stimulation was applied to SACs, four to five glomeruli distant from the recorded ETC (Fig. 2G, top). Optical stimulation reliably evoked an outward current in ETCs (Fig. 2G,H). This outward synaptic 
A

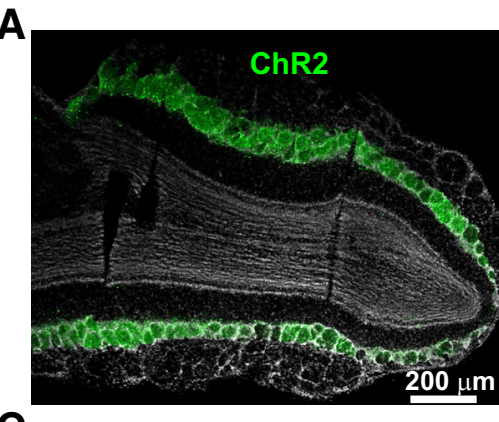

C

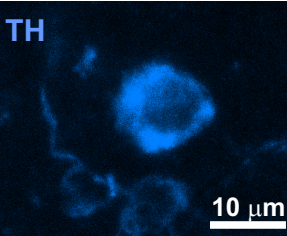

B
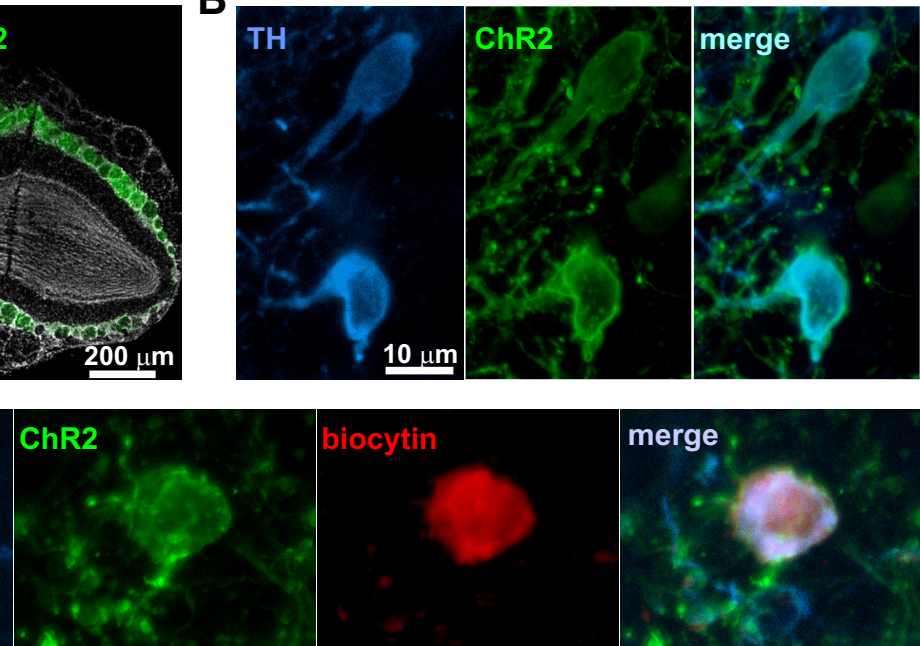

D

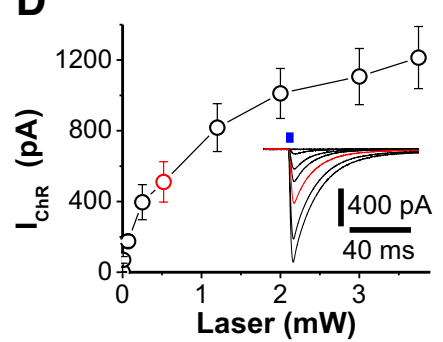

E
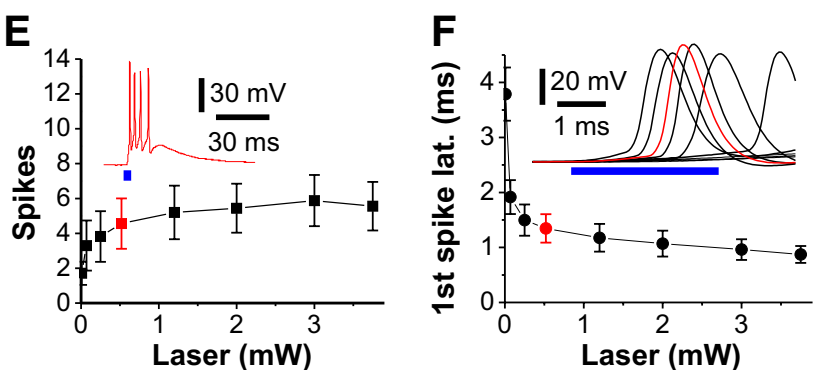

G
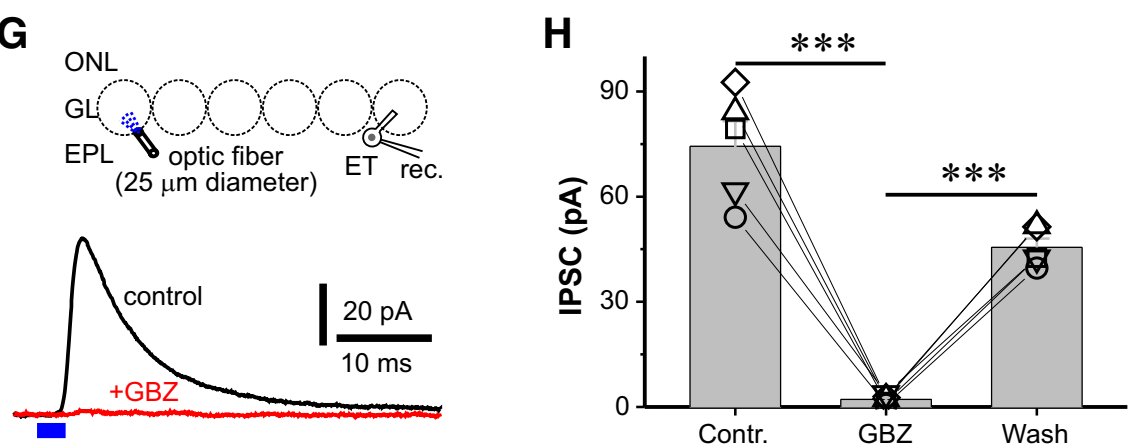

Figure 2. Activation of DAergic SACs generates an inhibitory monosynaptic response in ETCs in the IGCs with optogenetic approach. $A$, Confocal image of a horizontal OB section showing the expression of ChR2-EYFP (green) selectively in the GL. B, Confocal images showing the colocalization of TH protein (blue, left) and ChR2-EYFP (green, middle) in SACs. C, One recorded SACs labeled with three markers. TH protein (blue), ChR2-EYFP (green), and biocytin (red) filled via a whole-cell patch electrode. $\boldsymbol{D}-\boldsymbol{F}$, Population data plotting the peak amplitude of ChR2 current ( $\boldsymbol{D}, n=5$ cells), spikes numbers evoked each laser light exposure $(\boldsymbol{E}, n=5$ cells), or the first spike latency $(\boldsymbol{F}, n=5$ cells) against the power of laser light ( $3 \mathrm{~ms}$ duration) in $S A C s$. Insets, $\boldsymbol{D}$, Typical traces showing ChR2 currents evoked by laser light at increasing power; $\boldsymbol{E}$, representative current-clamp response trace showing spikes evoked by laser light exposure at power level as indicated in the plotting graph (red); $\boldsymbol{F}$, typical current-clamp recording traces showing the first spike latency decreases with incremental laser power. $\mathbf{G}$, Top shows experimental design; bottom shows ETC synaptic currents in response to optical stimulation of SACs in distant glomeruli before (control) and after $(10 \mu \mathrm{M}) \mathrm{GBZ}$. EPL, External plexiform layer. $\boldsymbol{H}$, Population data showing that GBZ reversibly abolishes the outward synaptic current in ETCs $(n=5)$ evoked by stimulation of distant glomeruli. *** $p<0.001$ ( $n=5$ cells, one-way repeated-measure ANOVA with Bonferroni's test).

current was reversibly abolished by $10 \mu \mathrm{M} \mathrm{GBZ}(74.4 \pm 7.2 \mathrm{pA}$ in control vs $2.2 \pm 0.5 \mathrm{pA}$ in GBZ; $n=5, p<0.001$ ), indicating a $\mathrm{GABA}_{\mathrm{A}}$ receptor-mediated IPSC triggered by optical stimulation of SACs. To estimate the latency of this optical stimulationevoked IPSC, we measured the time from the onset of light to the onset of the IPSC and subtracted $1.3 \mathrm{~ms}$, which is the average latency of the first spike elicited in SACs by $520 \mu \mathrm{W}$ optical stimulation. The average latency of optically evoked IPSCs in five ETCs was $2.15 \pm 0.12 \mathrm{~ms}$ (range of $1.73-2.69 \mathrm{~ms}$ ), and the jitter was $139.28 \pm 14.25 \mu$ s (range of $89.46-178.37 \mu \mathrm{s} ; n=5$ cells). These values are consonant with the latencies measured with electrical stimulation and are consistent with monosynaptic transmission (Doyle and Andresen, 2001). Together, these exper- iments indicate that $\mathrm{SAC}$ interglomerular synapses release GABA that produces monosynaptic $\mathrm{GABA}_{\mathrm{A}}$ receptor-mediated inhibition in ETCs.

\section{Interglomerular inhibition produces a rebound excitation in ETCs}

How does SAC inhibitory input impact ETC output? ETCs generate spontaneous bursts of action potentials (Hayar et al., 2004b; Liu and Shipley, 2008a). Each burst contains two to five action potentials with different ETCs generating spontaneous bursts at different burst frequencies ranging from 0.15 to $11 \mathrm{~Hz}$ (mean, $3.3 \pm 0.14 \mathrm{~Hz} ; n=288$ cells) (Liu et al., 2012). Light activation of SACs in distant glomeruli reproducibly evoked IPSPs, which ter- 

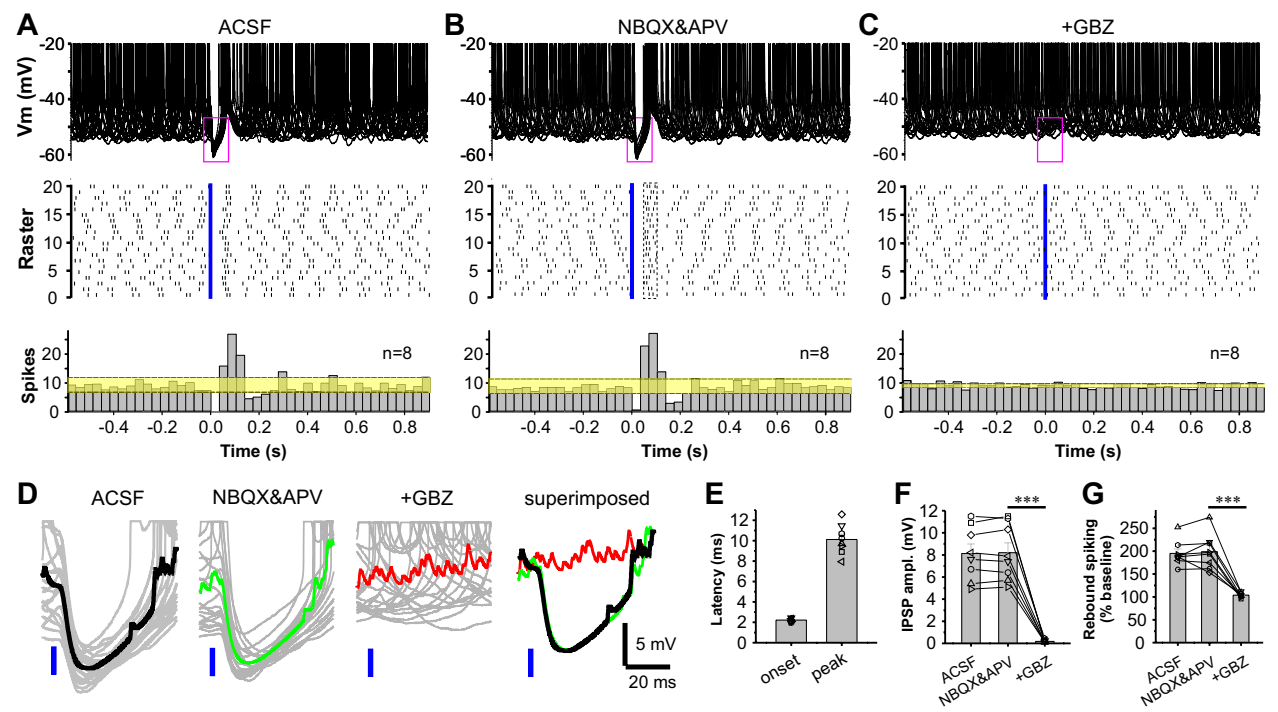

Figure 3. Optical stimulation of $S A C S$ generates a $G A B A_{A}$ receptor-mediated monosynaptic IPSP, followed by rebound excitation in ETCs. $A-C$, Top, Twenty current-clamp traces showing

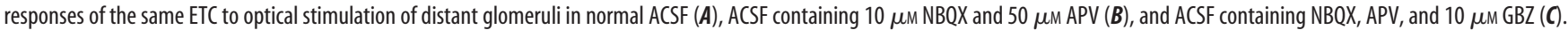
Middle, Raster plots showing spike distribution across 20 individual traces in corresponding conditions. Blue vertical lines indicate the blue laser light exposure. Bottom, Spike histogram averaged from eight ETCs (20 traces/cell) showing fast inhibition, followed by rebound excitation in response to optical stimulation of distant glomeruli in corresponding conditions shown in the top. $\boldsymbol{D}$, Close-up of IPSPs evoked by optical stimulation of distant glomeruli within the purple rectangles shown in the corresponding top panels. Thick traces represent the average from 20 traces (gray). $\boldsymbol{E}$, Population data showing the IPSP onset and peak latencies $(n=8$ cells). $\boldsymbol{F}, G$, Population data from eight cells showing the effects of NBQX + APV, or NBQX + APV plus GBZ on IPSP amplitude $(\boldsymbol{F})$ and rebound spiking (G). ${ }^{* *} p<0.001$ ( $n=8$ cells, one-way repeated-measure ANOVA with Bonferroni's test).

minated spontaneous bursting in ETCs (Fig. 3A). The optically evoked IPSP had an onset latency of $2.2 \pm 0.1 \mathrm{~ms}$ and reached peak amplitude $(8.1 \pm 0.9 \mathrm{mV}, n=8$ cells $)$ at $10.1 \pm 0.5 \mathrm{~ms}(n=$ 8 cells). Inhibition of spiking was invariably followed by a rebound spike burst (Fig. 3A). Neither the optically evoked IPSP $(8.1 \pm 0.9 \mathrm{mV}$ in ACSF vs $8.2 \pm 0.9 \mathrm{mV}$ in NBQX $+\mathrm{APV}, n=8$, $p>0.05$; Fig. $3 D, F)$ nor the rebound spike burst (195.0 $\pm 9.7 \%$ in ACSF vs $199.0 \pm 13.7 \%$ in NBQX + APV $, n=8, p>0.05$; Fig. $3 A, B, G)$ were altered by blocking fast glutamatergic transmission with NBQX $(10 \mu \mathrm{M})$ and APV $(50 \mu \mathrm{M}$; Fig. $3 B)$. Thus, SAC $\rightarrow$ ETC inhibition-excitation sequence does not depend on excitatory elements. In contrast, GBZ $(10 \mu \mathrm{M})$ completely abolished both the IPSPs (Fig. 3C, D, F, $8.2 \pm 0.9 \mathrm{mV}$ in NBQX + APV vs $0.2 \pm 0.1 \mathrm{mV}$ in NBQX + APV plus GBZ; $n=8, p<0.001)$ and the rebound burst (Fig. 3C, G, $199.0 \pm 13.7 \%$ in NBQX + APV vs $103.8 \pm 1.9 \%$ in NBQX + APV plus GBZ; $n=8, p<0.001)$. Together, these data show that GABA release from SACs is necessary and sufficient for the inhibition-excitation response in ETCs.

\section{DA produces an $I_{h}$-mediated inward current via $D_{1}$-like receptors in ETCs}

Coexpression of TH suggests that SACs also release DA, but direct physiological evidence for this is lacking. If DA is synaptically released with GABA from SACs, what is its postsynaptic action in ETCs? To address this, we first examined the effect of exogenous DA to determine whether ETCs express DA receptors, which receptor types, and characterize the currents DA generates in ETCs. In the presence of ionotropic glutamate (iGluR) and $\mathrm{GABA}_{\mathrm{A}}$ receptor blockers $(10 \mu \mathrm{M}$ NBQX, $50 \mu \mathrm{M} \mathrm{APV}$, and $10 \mu \mathrm{M}$ GBZ) to minimize circuit effects, bath application of DA (20 $\mu \mathrm{M})$ reliably produced an apparent inward current with peak amplitude of $8.1 \pm 1.5 \mathrm{pA}(n=6)$ in ETCs held at $-55 \mathrm{mV}$ (Fig. $4 A, C)$. Application of the selective $\mathrm{D}_{1}$-like receptor antagonist SCH39166 $(10 \mu \mathrm{M})$ blocked the DA $(20 \mu \mathrm{M})$-induced inward current; a residual small outward current was present in four of six cells $(2.5 \pm 0.6 \mathrm{pA}, n=4, p<0.05$, Kolmogorov-Smirnov test). Addition of the $\mathrm{D}_{2} \mathrm{R}$ antagonist $S$ - $(-)$-sulpiride $(50 \mu \mathrm{M}$; Fig. $4 A, C)$ with the $\mathrm{D}_{1} \mathrm{R}$ antagonist abolished this current $(0.18 \pm 0.11 \mathrm{pA}, n=5, p<0.001)$. These results indicate that the predominant effect of DA is an inward current that is mediated by $\mathrm{D}_{1}$-like receptors in all ETCs. In separate experiments the $\mathrm{D}_{1}$-like receptor agonist DHX $(10 \mu \mathrm{M})$ produced an inward current $(14.5 \pm 3.2 \mathrm{pA}, n=5, p>0.05$ compared with the DAinduced inward current of $8.1 \pm 1.5 \mathrm{pA}, n=6$ ); the DHX inward current was completely blocked by the selective $\mathrm{D}_{1}$-like receptor antagonist SCH39166 $(10 \mu \mathrm{M}, 0.6 \pm 0.2 \mathrm{pA}, n=5, p<0.001$ compared with DHX alone; Fig. $4 B, C$ ). These results show that DA has a predominantly excitatory effect mediated by $\mathrm{D}_{1}$-like receptors in all ETCs and a fourfold smaller inhibitory effect mediated by $\mathrm{D}_{2}$-like receptors in some ETCs.

ETCs respond to exogenous DA, but do they respond to DA released from SACs? Optical stimulation of distant glomeruli induced an inward current $(5.2 \pm 1.0 \mathrm{pA}, n=5)$ in the presence of GBZ to eliminate the GABA-mediated IPSCs. This inward current was eliminated by a selective $\mathrm{D}_{1}$-like receptor antagonist (SCH39166 at $10 \mu \mathrm{M}, n=5, p<0.001$; Fig. $4 D, E$ ). This shows that SACs release both DA and GABA onto ETCs generating a $\mathrm{GABA}_{\mathrm{A}}$ receptor-mediated outward (hyperpolarizing) current and $\mathrm{DA}-\mathrm{D}_{1}$-like receptor-mediated inward (depolarizing) current.

$D_{1}$-like receptors are G-protein-coupled metabotropic receptors whose downstream transduction pathways target multiple membrane conductances, including sodium currents, hyperpolarization-activated cation current, calcium currents, and potassium currents (Schiffmann et al., 1998; Zhang et al., 1998, 2002; Dong and White, 2003; Chen and Yang, 2007; Kisilevsky et al., 2008; So et al., 2009; Ballo et al., 2010). Many of these conductances regulate ETC spontaneous bursting (Liu and Shipley, 2008a). To determine which ETC conductances are modulated by $\mathrm{D}_{1}$-like receptor activation, we first determined whether the effects of DA on ETCs were persistent or transient. A 

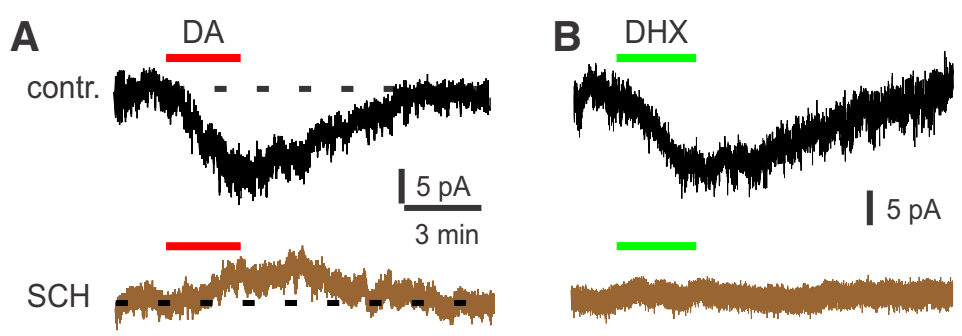

sul.

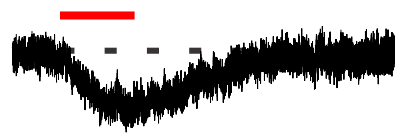

$\mathrm{SCH}$

\&sul.
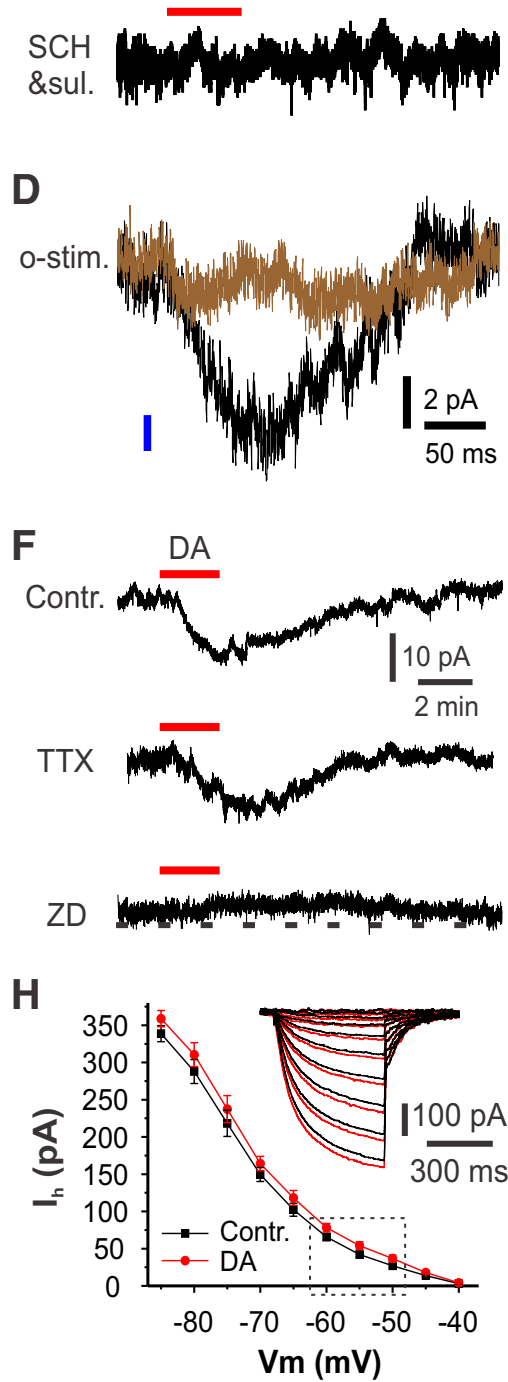
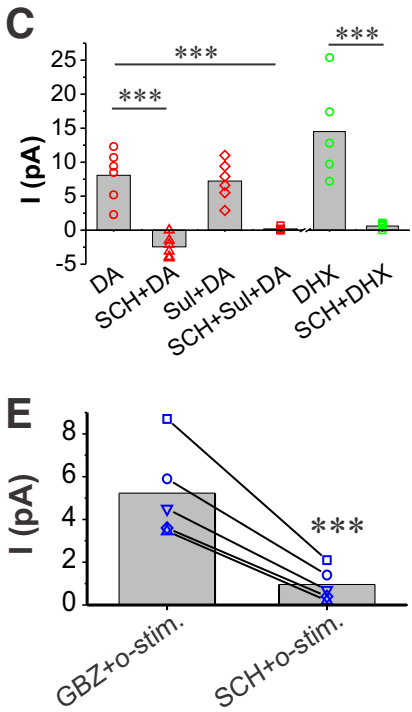

G

I

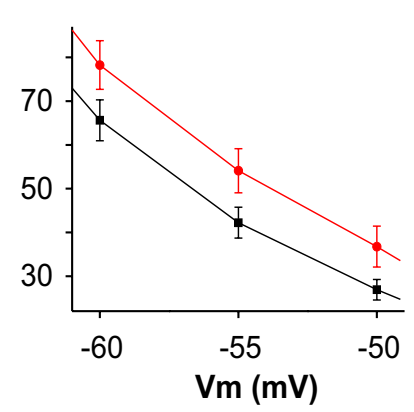

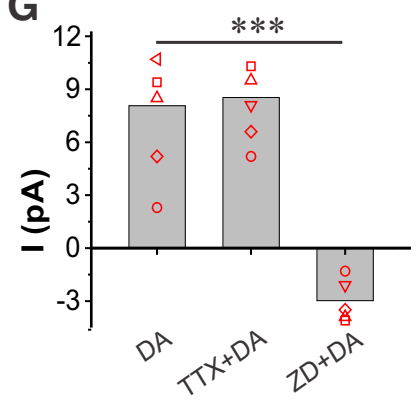

Figure 4. DA produces an apparent inward current by enhancing $I_{\mathrm{h}}$ in ETCS. $A$, Current traces showing effects of the selective $\mathrm{D}_{1}$-like receptor antagonist $\mathrm{SCH} 39166\left(\mathrm{SCH}, 10 \mu \mathrm{m}\right.$, brown), the selective $\mathrm{D}_{2}$-like receptor antagonist ( $\left.\mathrm{S}\right)$-( - )-sulpiride (sul., 50 $\mu \mathrm{M})$, or SCH39166 plus (S)-(-)-sulpiride (SCH\&sul.) on inward current induced by bath application of exogenous DA (20 $\mu \mathrm{M}$, red bar). $\boldsymbol{B}$, Current traces showing that the selective $\mathrm{D}_{1}$-like receptor agonist DHX (10 $\left.\mu \mathrm{m}\right)$-induced inward current is abolished by SCH39166 (brown). C, Population data from ETCs as shown in $\boldsymbol{A}$ and $\boldsymbol{B}$. Red symbols represent DA experiments, and green symbols stand for DHX experiments. Symbol shapes represent different treatments. ${ }^{* * *} p<0.001$ (one-way ANOVA with Bonferroni's test, $n=6$ cells in DA experiments and $n=5$ cells in DHX experiments). $\boldsymbol{D}$, (urrent traces showing response of the same ETC to optical stimulation (blue vertical bar) of a distant glomerulus before (black) and after (10 $\mu \mathrm{m}$, brown) SCH39166. E, Population data from five ETCS showing that the optical activation of distant SACs evoked an apparent inward current that is significantly attenuated by SCH39166. ${ }^{* * *} p<0.001$ ( $n=5$ cells, paired Student's t test). $\boldsymbol{F}$, Current traces showing ETC response to bath-applied DA (20 $\left.\mu \mathrm{M}\right)$ in ACSF (contr), with the addition of TTX $(1 \mu \mathrm{M})$ or ZD7288 (ZD, $20 \mu \mathrm{M})$. G, Population data showing the DA-induced inward current.

10 min perfusion of DA $(20 \mu \mathrm{M})$ produced an apparent inward current that showed no inactivation throughout the application, indicating that DA modulates one or more non-inactivating conductances. Because the persistent sodium current $\left(I_{\mathrm{NaP}}\right)$ and $I_{\mathrm{h}}$ are both noninactivating currents in ETCs (Liu and Shipley, 2008a), we investigated these two conductances. In the presence of the selective sodium channel blocker TTX $(1 \mu \mathrm{M})$, DA $(20 \mu \mathrm{M})$ induced an inward current $(8.5 \pm 1.0 \mathrm{pA}, n=6)$ that was indistinguishable from that in control $(8.1 \pm 1.5$ pA, $n=6, p>0.05$; Fig. $4 F, G)$. This indicates that DA does not modulate $I_{\mathrm{NaP}}$ in ETCs. In contrast, the selective $I_{\mathrm{h}}$ channel blocker ZD7288 (20 $\mu \mathrm{M})$ abolished the DA-induced inward current (Fig. $4 F, G$ ). This suggests that the DA-induced inward current is attributable to enhancement of $I_{\mathrm{h}}$. This was further confirmed by experiments (Fig. $4 H, I$ ) showing that $I_{\mathrm{h}}$ current activated by hyperpolarizing voltage steps (500 ms, $5 \mathrm{mV} / \mathrm{step}$ ) was enhanced by $11.4 \pm 3.9 \mathrm{pA}(n=6$ cells $)$ by DA $(20 \mu \mathrm{M})$ over a voltage range from -85 to -50 $\mathrm{mV}$. Together, these results indicate that DA acts via $D_{1}$-like receptors to enhance $I_{\mathrm{h}}$ and produce an inward current in ETCs.

\section{DA enhances ETC spontaneous bursting via $D_{1}$-like receptors}

The physiological hallmark of ETCs is their spontaneous burst firing behavior (Hayar et al., 2004b; Liu and Shipley, 2008a). The frequency of spontaneous bursting is voltage dependent, i.e., it increases with membrane depolarization and decreases with hyperpolarization (Hayar et al., 2004b). ETCs provide excitatory input to and receive synaptic feedback from the majority $(\sim 70 \%)$ of SACs (Hayar et al., 2004a; Kiyokage et al., 2010). Thus, ETC spontaneous bursting might generate DA release from SACs, and, because DA enhances $I_{\mathrm{h}}$ current in ETCs, DA feedback might increase ETC spontaneous bursting frequency. To test this, we made cell-attached recordings of ETC spontaneous bursting before and after application of DA. As shown in Figure 5, DA (20 $\mu \mathrm{M})$ reversibly increased spontaneous burst

\section{$\leftarrow$}

is abolished by the $\mathrm{h}_{\mathrm{h}}$-selective blocker ZD7288 but not by $\Pi \mathrm{TX}{ }^{* * *} \mathrm{p}<$ 0.001 ( $n=5$ cells, one-way ANOVA with Bonferroni's test) $\boldsymbol{H}$, Population $l-V$ curve showing that DA enhances $I_{h}$ in six of six cells tested. Inset, Current traces showing ET Cresponses to hyperpolarizing voltage steps (5 mV/step) in the absence (black) or presence (red) of DA. I, Close-up of the $I_{\mathrm{h}} I-V$ curveshown in $H$ in the voltage rangefrom -60 to $-50 \mathrm{mV}$. 

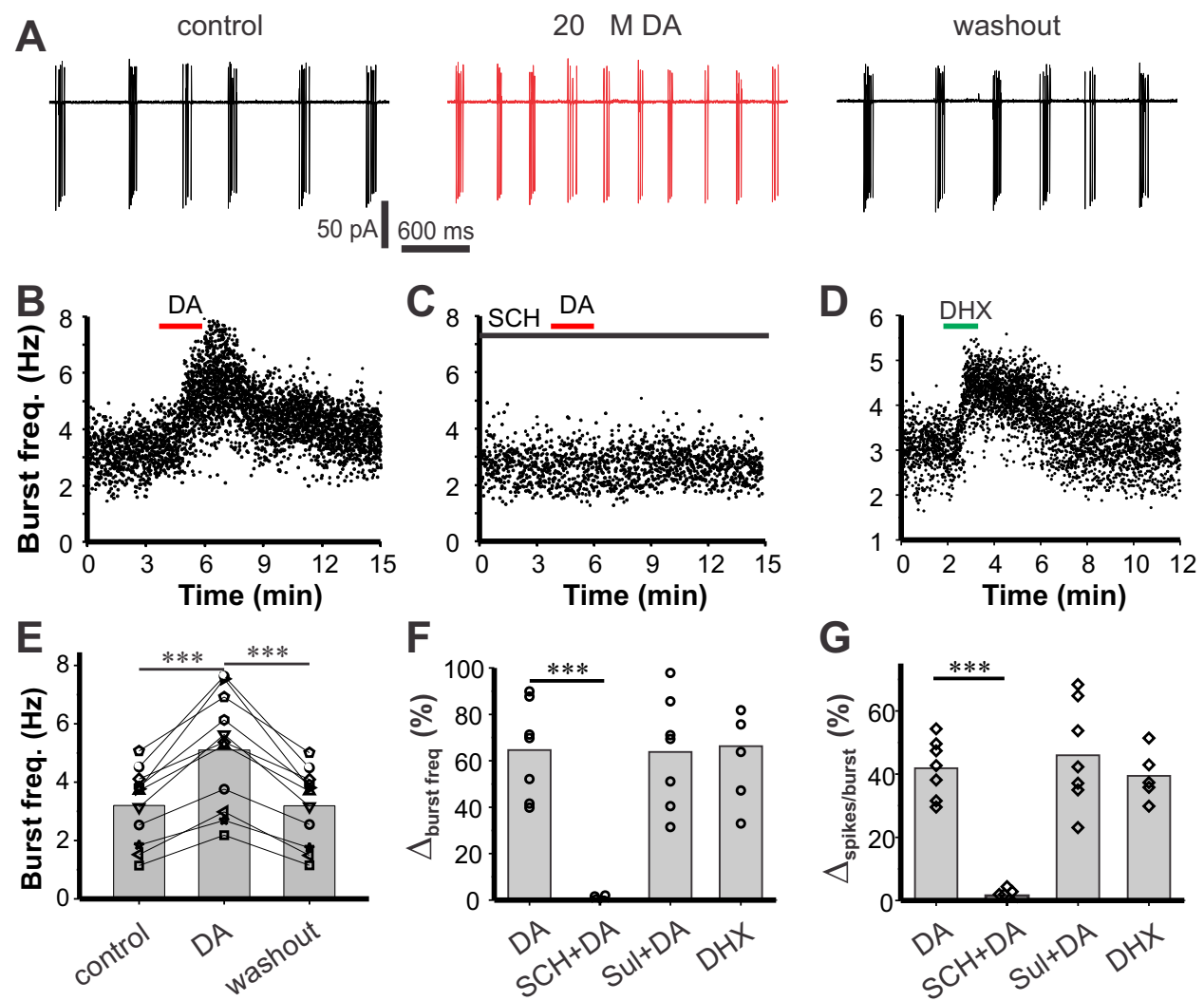

$\mathbf{F}$

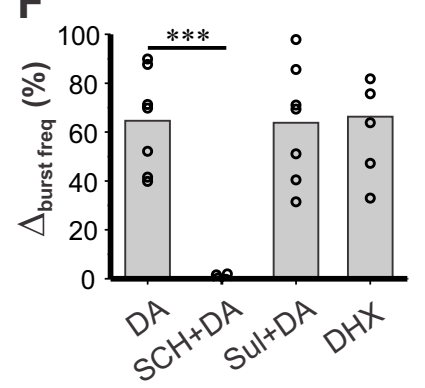

G

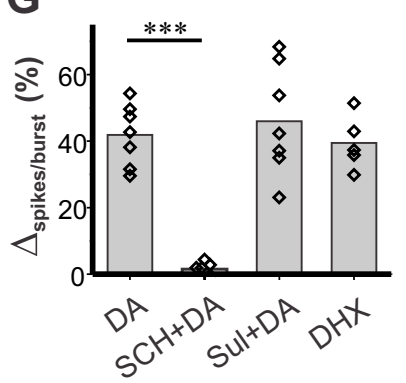

Figure 5. DA increases spontaneous burst frequency in ETCS. $A$, Cell-attached traces showing spontaneous burst firing in an ETC before (control), during ( $20 \mu \mathrm{m} \mathrm{DA}$, red), and after washout of DA. $B$, Scatter plot showing that DA increases frequency of spontaneous bursting in the ETC shown in A. C, Scatter plot showing that DA increased spontaneous burst frequency is completely blocked by SCH39166 (SCH, $10 \mu \mathrm{m})$. D, Scatter plot showing that frequency of spontaneous bursting is reversibly increased by the selective $\mathrm{D}_{1}$-like agonist DHX (10 $\left.\mu \mathrm{m}\right)$. $\boldsymbol{E}$, Population data showing that spontaneous burst frequency in $11 \mathrm{ETC}$ s is reversibly enhanced by DA $(20 \mu \mathrm{M}){ }^{* * *} p<0.001$ ( $n=11$ cells, one-way repeated-measure ANOVA with Bonferroni's test). $\boldsymbol{F}, \mathbf{G}, \mathbf{S}$ Satter plot showing that $\mathrm{DHX}(10 \mu \mathrm{m})$-induced or DA-induced increase in spontaneous burst frequency $(\boldsymbol{F})$ and spikes/burst $(\boldsymbol{G})$ in the absence (DA) or the presence of SCH39166 (10 $\mu \mathrm{M}, \mathrm{SCH}+\mathrm{DA})$ or $(\mathrm{S})-(-)$-sulpiride $(50$ $\mu \mathrm{m}$, Sul $+\mathrm{DA}$, ). ${ }^{* * *} p<0.001$ ( $n=7$ cells, one-way ANOVA with Bonferroni's test).

frequency by $\sim 60 \%$ (from $3.2 \pm 0.4$ to $5.1 \pm 0.6 \mathrm{~Hz} ; n=11, p<$ 0.001 ); increased burst frequency was associated with decreased spikes/burst (from $4.4 \pm 1.3$ to $3.6 \pm 1.0 ; n=11, p<0.001$ ) in all cells tested (Fig. $5 A, B, E$ ). This is consistent with the previous finding that depolarization increases spontaneous bursting frequency but decreases spikes per burst (Hayar et al., 2004b). We next asked whether the DA-mediated increase in ETC spontaneous bursting is attributable to activation of $\mathrm{D}_{1}$-like receptors. Indeed, the selective $\mathrm{D}_{1}$-like receptor antagonist SCH39166 $(10 \mu \mathrm{M})$ completely blocked both the DA-induced increase in spontaneous burst frequency (64.6 $\pm 7.8 \%$ increase in bursting with DA alone compared with $0.3 \pm 0.7 \%$ increase when SCH39166 is present, $n=7, p<0.001$; Fig. 5C,F) and decreased spikes/burst $(20.9 \pm 1.8 \%$ decrease in spiking in DA alone compared with a decrease of $0.8 \pm 0.4 \%$ when SCH39166 is present, $n=7, p<0.001$; Fig. $5 G)$. The selective $\mathrm{D}_{1^{-}}$ like receptor agonist DHX $(10 \mu \mathrm{M})$ had a similar effect to DA on both spontaneous burst frequency (increase by $60.3 \pm 9.0 \%, n=5$; Fig. $5 F$ ) and spikes/burst (decrease by $19.7 \pm 1.8 \%, n=5$; Fig. $5 G$ ). These results support the conclusion that DA increases ETC spontaneous bursting via $\mathrm{D}_{1}$-like receptors by enhancing $I_{\mathrm{h}}$, which depolarizes the membrane.

Consistent with DA increasing ETC spontaneous bursting via $\mathrm{D}_{1}$-like receptors, the $\mathrm{D}_{1} \mathrm{R}$ antagonist $\mathrm{SCH} 39166(10 \mu \mathrm{M})$ reduces ETC spontaneous burst frequency (Fig. 5, compare $C, B$ ). This was further confirmed in subsequent experiments (Fig. 6C) showing that SCH39166 $(10 \mu \mathrm{M})$ reduced ETC spontaneous burst frequency by $30.6 \%$ from $3.6 \pm 0.7 \mathrm{~Hz}$ in NBQX and APV to $2.5 \pm 0.5 \mathrm{~Hz}$ with addition of SCH39166 ( $p<0.001, n=6)$. This suggests that spontaneous DA release from SACs feeds back onto ETCs.

\section{GABA-DA cotransmission generates a biphasic inhibition-} excitation response in ETCs

The preceding experiments show that SACs release both GABA and DA onto ETCs. GABA produces $\mathrm{GABA}_{\mathrm{A}}$ receptor-mediated monosynaptic inhibition of ETCs and DA enhances $I_{\mathrm{h}}$, which increases post-inhibition rebound depolarization and strengthens ETC spontaneous bursting. How do these opposing inhibitory and excitatory actions influence ETC spike output? To investigate this, we applied optical stimulation to distant glomeruli while recoding from ETCs in current clamp. Light activation evoked monosynaptic IPSPs that were followed by a strong rebound spike burst. Neither component of this biphasic response was affected by AMPA and NMDA receptor blockers (Fig. $6 A, B, E)$, indicating that iGluRs are not required for the inhibition-excitation sequence. However, the selective $\mathrm{D}_{1}$-like receptor antagonist SCH39166 $(10 \mu \mathrm{M})$ significantly attenuated the post-IPSP rebound spiking from $185.2 \pm 9.5$ to $153.3 \pm 8.8 \%$ of baseline spontaneous burst spiking $(n=6, p<0.01$; Fig. $6 B, C, E) . \mathrm{D}_{1}$-like receptor block also increased the evoked IPSP duration ( $58.4 \pm 4.3$ to $74.4 \pm 5.7 \mathrm{~ms} ; p<0.01)$ and decay time constant $(32.9 \pm 3.7$ to $44.1 \pm 5.4 \mathrm{~ms} ; p<0.01)$ in six of six cells tested (Fig. $6 D-H)$. These changes in IPSP kinetics were not associated with any significant change in IPSP amplitude (Fig. 6D). 

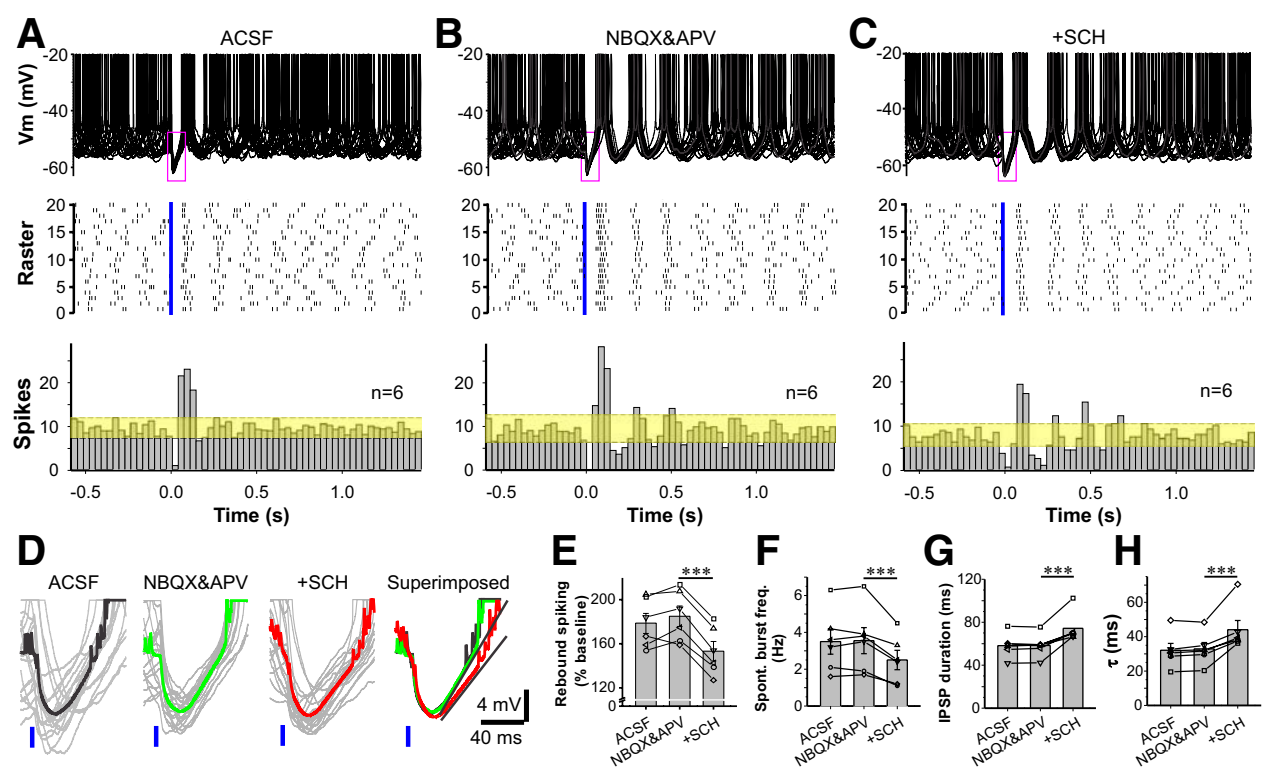

Figure 6. Optical stimulation of $S A C s$ produces a $D_{1}$ receptor-mediated enhancement of rebound excitation in interglomerular ETCS. $A-C$, Top, Twenty current-clamp traces showing responses of the same ETC to optical stimulation of distant glomeruli in normal ACSF (A), ACSF containing $10 \mu \mathrm{m} \mathrm{NBQX}+50 \mu \mathrm{m} \mathrm{APV} \mathrm{(B),} \mathrm{and} \mathrm{ACSF} \mathrm{containing} \mathrm{NBQX} \mathrm{+} \mathrm{APV} \mathrm{plus} 10 \mu \mathrm{m}$ SCH39166 (C). Middle, Raster plots showing spike distribution for 20 individual traces in corresponding conditions. Blue vertical lines indicate the blue laser light exposure. Bottom, Spike histogram averaged from six ETCs (20 traces/cell) showing the rebound spikes to optical stimulation of distant glomeruli in corresponding conditions shown in the top. D. Close-up IPSPs evoked by optical stimulation of distant glomeruli within the purple rectangles shown in the corresponding top panels. Thick traces represent the average from 20 traces (gray). $E-H$, Population data showing the effect of NBQX $+A P V$ and $\mathrm{NBQX}+\mathrm{APV}$ plus SCH on the optically evoked rebound spiking $(\boldsymbol{E})$, spontaneous burst frequency $(\boldsymbol{F})$, duration $(\boldsymbol{G})$, and decay $(\boldsymbol{H})$ of the optical stimulation-evoked IPSP in six ETCs. ${ }^{* * *} p<0.001$ ( $n=6$ cells, one-way repeated-measure ANOVA with Bonferroni's test).

These results show that DA- $\mathrm{D}_{1} \mathrm{R}$ enhancement of $I_{\mathrm{h}}$ strengthens the rebound spike burst that follows the initial GABAergic inhibition. Together, these findings demonstrate that GABA and DA cotransmission from SACs generates a temporally biphasic inhibition-to-excitation response in ETCs of neighboring glomeruli.

\section{Discussion}

We provide evidence that SACs release both GABA and DA to produce a biphasic inhibition-excitation response in ETCs in neighboring glomeruli. GABA causes fast inhibition via ionotropic $\mathrm{GABA}_{\mathrm{A}}$ receptors, whereas DA generates a slower excitatory response via metabotropic $\mathrm{D}_{1}$-like receptors. These opposing actions are orchestrated by $I_{\mathrm{h}}$, a prominent hyperpolarization-activated, cyclic nucleotide-gated conductance in ETCs. GABA-mediated hyperpolarization engages $I_{\mathrm{h}}$, which repolarizes the membrane toward the threshold for spiking; DA enhances $I_{\mathrm{h}}$, further strengthening the rebound spike burst. Thus, two transmitters acting via the same intrinsic current produce a biphasic inhibition-excitation response in ETCs, neurons that play a key role in gating the glomerulus inputoutput function.

\section{GABA and DA release from SACs to ETCs}

DA is released from the terminals of VTA neurons projecting to the nucleus accumbens in the midbrain; VTA neuron synapses corelease the excitatory transmitter glutamate in addition to DA (Chuhma et al., 2004, 2009; Hnasko et al., 2010; Stuber et al., 2010; Tecuapetla et al., 2010; Yamaguchi et al., 2011). Recent studies showed that DA terminals in the striatum can corelease DA, GABA, and glutamate (Tritsch et al., 2012), although when iGluRs and $\mathrm{GABA}_{\mathrm{A}}$ receptors were blocked, postsynaptic DA responses were not detected, presumably because of their small current size.

Olfactory bulb SACs coexpress markers for GABA and DA (Hökfelt et al., 1975; Baker et al., 1983; Kosaka et al., 1985;
Goheen Robillard et al., 1997; Kosaka and Kosaka, 2008; Maher and Westbrook, 2008; Kiyokage et al., 2010), and SACs synaptically target multiple glomeruli forming the IGC (Aungst et al., 2003; Kosaka and Kosaka, 2008; Kiyokage et al., 2010). Although the coexistence of markers for GABA and DA in SACs is well established, there is little evidence that these two transmitters are coreleased. The finding that direct activation of $\mathrm{TH}^{+}$cells produced $G_{A B A} R$-mediated self-inhibition and $D A-D_{2} R$ mediated presynaptic inhibition in the GL is consistent with this notion (Maher and Westbrook, 2008). The present experiments provide the first evidence that SACs release both GABA and DA onto ETCs. Optical activation of $\mathrm{ChR} 2{ }^{+} \mathrm{SACs}$ evokes $\mathrm{GABA}_{\mathrm{A}} \mathrm{R}$ mediated IPSCs with a latency of $\sim 2.2 \mathrm{~ms}$, consistent with monosynaptic input. The IPSC is followed by an excitatory response that persists when the IPSC is blocked by GBZ but is blocked by $\mathrm{D}_{1} \mathrm{R}$ antagonists. Thus, in contrast to the striatum, in which direct postsynaptic DA responses were not seen, activation of SACs generates a clear DA response in ETCs.

SACs are generated throughout adult life, and 97\% coexpress TH and GAD67 (Kiyokage et al., 2010). As they mature, TH promoter activity and mRNA expression occur in advance of TH protein (Baker et al., 1983; Baker et al., 2001). Thus, a proportion lack $\mathrm{TH}$ protein but express $\mathrm{TH}-\mathrm{Cre}$ and can transform the AAV-ChR2 construct. Of the glomerular neurons expressing ChR2, 91\% stain for $\mathrm{TH}$ protein, a ratio similar to that of $\mathrm{TH}$ promoter-driven transgenes to TH protein (Baker et al., 1983, 2001). Conceivably, the few ChR2 ${ }^{+} \mathrm{TH}$-negative neurons may express other transmitters, but the finding that optically evoked $\mathrm{SAC} \rightarrow$ ETC responses are unaltered by iGluR blockers excludes glutamate.

Together, the most parsimonious interpretation of the present findings is that glomerular SACs corelease or cotransmit GABA and DA onto ETCs. Corelease implies that a neuron re- 
leases two transmitters from the same synaptic vesicle; alternatively, the two transmitters may be released from different vesicles in the same neuron-cotransmission. Compelling evidence for GABA-DA corelease in the striatum was demonstrated recently by showing that GABA and DA are sequestered by a vesicular monoamine transporter (VMAT2) into the same vesicles in DA terminals (Tritsch et al., 2012). Additional compelling evidence for DA-GABA corelease has been documented in retina (Hirasawa et al., 2012). Activation of single dissociated DAergic amacrine cells generated simultaneous DA-GABA release events and EM immunostaining showed that some secretory organelles contained both VMAT2 and vesicular GABA transporter (VGAT). It is not known whether DA and GABA are contained in the same or different vesicles in SAC terminals. Future experiments testing SAC $\rightarrow$ ETCs response in mice lacking specific vesicular transporters and/or immunostaining for VMAT and VGAT might shed light on this. Dual patch-clamp experiments in which single identified SACs are stimulated while recording ETCs might provide more direct evidence for corelease. However, single SACs make sparse contacts with multiple neighboring glomeruli (Kiyokage et al., 2010), suggesting that postsynaptic impact depends on convergent inputs from multiple SACs; thus, activation of single SACs might not evoke consistently detectable responses in ETCs.

\section{GABA and DA acting via $I_{\mathrm{h}}$ generate an inhibition-excitation response sequence}

SAC release of GABA and DA evokes a biphasic inhibition-excitation response in ETCs via $\mathrm{GABA}_{\mathrm{A}}$ Rs and G-protein-coupled $\mathrm{D}_{1}$-like receptors. How are these opposing synaptic actions orchestrated to shape ETC output? ETCs express a strong $I_{\mathrm{h}}$ conductance, which is partially active at resting membrane potential (Hayar et al., 2004b; Liu and Shipley, 2008a). $I_{\mathrm{h}}$ is strongly activated by IPSPs and plays a major role in post-inhibitory rebound spike bursting (Liu and Shipley, 2008b). We showed that both endogenous and exogenous DA activates $\mathrm{D}_{1}$ Rs, which enhance $I_{\mathrm{h}}$ to excite ETCs. $\mathrm{D}_{1}$ R-like enhancement of $I_{\mathrm{h}}$ occurs in rat neocortical interneurons (Wu and Hablitz, 2005) and retinal ganglion cells (Chen and Yang, 2007). Thus, DA modulation of neuron excitability via $I_{\mathrm{h}}$ is not unique to ETCs.

SAC release of GABA activates $\mathrm{GABA}_{\mathrm{A}}$ receptors and produces IPSPs and inhibits spiking in ETCs. The hyperpolarization activates $I_{\mathrm{h}}$, a depolarizing current that drives the membrane to more positive potentials activating $I_{\mathrm{NAP}}$ and $I_{\mathrm{T} / \mathrm{L}}$. When $I_{\mathrm{h}}$ is blocked, there is less activation of these depolarizing conductances that contribute to spike bursts (Liu and Shipley, 2008a). SAC DA release enhances $I_{\mathrm{h}}$, increasing depolarization and rebound spiking. $\mathrm{GABA}_{\mathrm{A}} \mathrm{Rs}$ mediate fast membrane changes, whereas $\mathrm{G}$-protein-coupled $\mathrm{D}_{1} \mathrm{Rs}$ involve slower multistage signaling cascades; thus, there is a time lag between the actions of the two transmitters. As a result, the ETC is initially inhibited and then switched to a DA-enhanced, $I_{\mathrm{h}}$-dependent rebound excitation.

\section{Circuit implications}

Electrical stimulation of the IGC causes $\mathrm{GABA}_{\mathrm{A}} \mathrm{R}$-mediated inhibition of ON-evoked long-lasting depolarizations (LLDs) in mitral cells (Aungst et al. 2003; Shirley et al., 2010). SACs generate a biphasic inhibition-excitation response in ETCs, which monosynaptically excite M/TCs (Hayar et al., 2004a; De Saint Jan et al., 2009; Gire et al., 2012). How might the biphasic action of SACs impact the ETC $\rightarrow \mathrm{M}$ /TC pathway to alter glomerular output? ON input to a glomerulus would increase activity of its SACs.
This should cause transient inhibition followed by rebound excitation of ETCs of neighboring glomeruli. While inhibited, ETCs should be less sensitive to $\mathrm{ON}$ input; this should reduce $\mathrm{ON} \rightarrow$ ETC $\rightarrow$ M/TC excitation. ETCs also give strong monosynaptic input to local GABAergic PGCs, which provide fast feedforward inhibition of M/TCs (Shao et al., 2012). SAC inhibition of ETCs should decrease excitatory drive on PGCs reducing inhibitory inputs to M/TC. Thus, SAC inhibition of ETCs might reduce excitatory drive on M/TCs while simultaneously reducing feed forward inhibition. If $\mathrm{M} / \mathrm{TC}$ receive the majority of their $\mathrm{ON}$ input via ETCs, as suggested by some (Gire et al., 2012), then SAC $\rightarrow$ ETC inhibition might render M/TCs less sensitive to sensory input. Alternatively, if $\mathrm{M} / \mathrm{TC}$ receive some direct $\mathrm{ON}$ input, as suggested by others (Najac et al., 2011; Shao et al., 2012), then $\mathrm{SAC} \rightarrow$ ETC inhibition should reduce excitatory drive of PGCs and decrease inhibition of M/TCs. This might increase M/TC sensitivity to direct $\mathrm{ON}$ inputs. If $\mathrm{M} / \mathrm{TC}$ are excited by both direct ON input and indirect input from ETCs, then SAC inhibition of ETCs could transiently shift the effectiveness of the two sources of sensory drive on glomerular output neurons. The ensuing period of post-inhibitory rebound excitation should increase the excitatory drive of ETCs on M/TCs, but this might be balanced by increased ETC $\rightarrow$ PGC $\rightarrow$ M/TC feedforward inhibition.

The balance between these excitatory and inhibitory actions is difficult to predict absent experimental evidence, but it seems likely that the timing of the SAC $\rightarrow$ ETC inhibition-excitation sequence will strongly influence the dynamics of sensory processing in neighboring glomeruli. Electrical stimulation of the isolated IGC inhibits ON-evoked LLDs in M/TCs, but the temporal dynamics of this inhibition have not been established (Aungst et al., 2003; Shirley et al., 2010). Finally, the impact of SACs on neighboring M/TCs may not be limited to their actions via ETCs. SACs may directly synapse onto M/TCs; preliminary experiments suggest that this is likely. Thus, SACs may directly and indirectly gate sensory coding in M/TCs.

Rodents sample odors by repetitive sniffing ranging from 1 to $10 \mathrm{~Hz}$. ETC spike bursts are entrained by repetitive $\mathrm{ON}$ inputs over this same frequency range; higher-frequency $\mathrm{ON}$ inputs entrain more ETCs (Hayar et al., 2004b). Because ETCs provide most of the excitatory input to SACs, higherfrequency sniffing may entrain more SACs (Wachowiak and Shipley, 2006). Our results show that ETCs are inhibited for $\sim 60$ ms after activation of SACs, after which they generate rebound bursting for $\sim 120 \mathrm{~ms}$. Thus, the "duty cycle" is $\sim 5$ $\mathrm{Hz}$, and rebound excitation lasts twice as long as the initial inhibition. Interestingly, animals exhibit sniff rates in this frequency range as they encounter novel odors (Verhagen et al., 2007; Wesson et al., 2008). Sniffing near $5 \mathrm{~Hz}$ might bring odor sampling in register with the SAC $\rightarrow$ ETC inhibitionexcitation duty cycle to optimize interglomerular regulation of sensory signals.

\section{References}

Aungst JL, Heyward PM, Puche AC, Karnup SV, Hayar A, Szabo G, Shipley MT (2003) Centre-surround inhibition among olfactory bulb glomeruli. Nature 426:623-629. CrossRef Medline

Baker H, Kawano T, Margolis FL, Joh TH (1983) Transneuronal regulation of tyrosine hydroxylase expression in olfactory bulb of mouse and rat. J Neurosci 3:69-78. Medline

Baker H, Liu N, Chun HS, Saino S, Berlin R, Volpe B, Son JH (2001) Phenotypic differentiation during migration of dopaminergic progenitor cells to the olfactory bulb. J Neurosci 21:8505-8513. Medline

Ballo AW, Keene JC, Troy PJ, Goeritz ML, Nadim F, Bucher D (2010) Do- 
pamine modulates Ih in a motor axon. J Neurosci 30:8425-8434. CrossRef Medline

Beaulieu JM, Gainetdinov RR (2011) The physiology, signaling, and pharmacology of dopamine receptors. Pharmacol Rev 63:182-217. CrossRef Medline

Berkowicz DA, Trombley PQ (2000) Dopaminergic modulation at the olfactory nerve synapse. Brain Res 855:90-99. CrossRef Medline

Björklund A, Dunnett SB (2007) Dopamine neuron systems in the brain: an update. Trends Neurosci 30:194-202. CrossRef Medline

Chen L, Yang XL (2007) Hyperpolarization-activated cation current is involved in modulation of the excitability of rat retinal ganglion cells by dopamine. Neuroscience 150:299-308. CrossRef Medline

Chuhma N, Zhang H, Masson J, Zhuang X, Sulzer D, Hen R, Rayport S (2004) Dopamine neurons mediate a fast excitatory signal via their glutamatergic synapses. J Neurosci 24:972-981. CrossRef Medline

Chuhma N, Choi WY, Mingote S, Rayport S (2009) Dopamine neuron glutamate cotransmission: frequency-dependent modulation in the mesoventromedial projection. Neuroscience 164:1068-1083. CrossRef Medline

Coronas V, Srivastava LK, Liang JJ, Jourdan F, Moyse E (1997) Identification and localization of dopamine receptor subtypes in rat olfactory mucosa and bulb: a combined in situ hybridization and ligand binding radioautographic approach. J Chem Neuroanat 12:243-257. CrossRef Medline

Dahlstroem A, Fuxe K (1964) Evidence for the existence of monoaminecontaining neurons in the central nervous system. I. Demonstration of monoamines in the cell bodies of brain stem neurons. Acta Physiol Scand Suppl 232:1-55. Medline

De Saint Jan D, Hirnet D, Westbrook GL, Charpak S (2009) External tufted cells drive the output of olfactory bulb glomeruli. J Neurosci 29:20432052. CrossRef Medline

Dong Y, White FJ (2003) Dopamine $\mathrm{D}_{1}$-class receptors selectively modulate a slowly inactivating potassium current in rat medial prefrontal cortex pyramidal neurons. J Neurosci 23:2686-2695. Medline

Doty RL (2012) Olfactory dysfunction in Parkinson disease. Nat Rev Neurol 8:329-339. CrossRef Medline

Doyle MW, Andresen MC (2001) Reliability of monosynaptic sensory transmission in brain stem neurons in vitro. J Neurophysiol 85:22132223. Medline

Ennis M, Zhou FM, Ciombor KJ, Aroniadou-Anderjaska V, Hayar A, Borrelli E, Zimmer LA, Margolis F, Shipley MT (2001) Dopamine D2 receptormediated presynaptic inhibition of olfactory nerve terminals. J Neurophysiol 86:2986-2997. Medline

Gall CM, Hendry SH, Seroogy KB, Jones EG, Haycock JW (1987) Evidence for coexistence of GABA and dopamine in neurons of the rat olfactory bulb. J Comp Neurol 266:307-318. CrossRef Medline

Gire DH, Schoppa NE (2009) Control of on/off glomerular signaling by a local GABAergic microcircuit in the olfactory bulb. J Neurosci 29:1345413464. CrossRef Medline

Gire DH, Franks KM, Zak JD, Tanaka KF, Whitesell JD, Mulligan AA, Hen R, Schoppa NE (2012) Mitral cells in the olfactory bulb are mainly excited through a multistep signaling path. J Neurosci 32:2964-2975. CrossRef Medline

Goheen Robillard B, Kott JN, Westrum LE (1997) Electron microscopy of colocalization of GABA and tyrosine hydroxylase expression in rat olfactory bulb transplants. Exp Neurol 143:219-230. CrossRef Medline

Greengard P (2001) The neurobiology of slow synaptic transmission. Science 294:1024-1030. CrossRef Medline

Gutièrrez-Mecinas M, Crespo C, Blasco-Ibáñez JM, Gracia-Llanes FJ, Marqués-Marí AI, Nácher J, Varea E, Martínez-Guijarro FJ (2005) Distribution of D2 dopamine receptor in the olfactory glomeruli of the rat olfactory bulb. Eur J Neurosci 22:1357-1367. CrossRef Medline

Hayar A, Karnup S, Ennis M, Shipley MT (2004a) External tufted cells: a major excitatory element that coordinates glomerular activity. J Neurosci 24:6676-6685. CrossRef Medline

Hayar A, Karnup S, Shipley MT, Ennis M (2004b) Olfactory bulb glomeruli: external tufted cells intrinsically burst at theta frequency and are entrained by patterned olfactory input. J Neurosci 24:1190-1199. CrossRef Medline

Hirasawa H, Betensky RA, Raviola E (2012) Corelease of dopamine and GABA by a retinal dopaminergic neuron. J Neurosci 32:13281-13291. CrossRef Medline
Hnasko TS, Chuhma N, Zhang H, Goh GY, Sulzer D, Palmiter RD, Rayport S, Edwards RH (2010) Vesicular glutamate transport promotes dopamine storage and glutamate corelease in vivo. Neuron 65:643-656. CrossRef Medline

Hökfelt T, Halasz N, Ljungdahl A, Johansson O, Goldstein M, Park D (1975) Histochemical support for a dopaminergic mechanism in the dendrites of certain periglomerular cells in the rat olfactory bulb. Neurosci Lett 1:8590. CrossRef Medline

Hopt A, Neher E (2001) Highly nonlinear photodamage in two-photon fluorescence microscopy. Biophys J 80:2029-2036. CrossRef Medline

Iversen SD, Iversen LL (2007) Dopamine: 50 years in perspective. Trends Neurosci 30:188-193. CrossRef Medline

Kisilevsky AE, Mulligan SJ, Altier C, Iftinca MC, Varela D, Tai C, Chen L, Hameed S, Hamid J, Macvicar BA, Zamponi GW (2008) D1 receptors physically interact with $\mathrm{N}$-type calcium channels to regulate channel distribution and dendritic calcium entry. Neuron 58:557-570. CrossRef Medline

Kiyokage E, Pan YZ, Shao Z, Kobayashi K, Szabo G, Yanagawa Y, Obata K, Okano H, Toida K, Puche AC, Shipley MT (2010) Molecular identity of periglomerular and short axon cells. J Neurosci 30:1185-1196. CrossRef Medline

Kosaka T, Kosaka K (2008) Tyrosine hydroxylase-positive GABAergic juxtaglomerular neurons are the main source of the interglomerular connections in the mouse main olfactory bulb. Neurosci Res 60:349-354. CrossRef Medline

Kosaka T, Hataguchi Y, Hama K, Nagatsu I, WU JY (1985) Coexistence of immunoreactivities for glutamate decarboxylase and tyrosine hydroxylase in some neurons in the periglomerular region of the rat main olfactory bulb: possible coexistence of gamma-aminobutyric acid (GABA) and dopamine. Brain Res 343:166-171. CrossRef Medline

Koster NL, Norman AB, Richtand NM, Nickell WT, Puche AC, Pixley SK, Shipley MT (1999) Olfactory receptor neurons express D2 dopamine receptors. J Comp Neurol 411:666-673. CrossRef Medline

Kruzich PJ, Grandy DK (2004) Dopamine D2 receptors mediate two-odor discrimination and reversal learning in C57BL/6 mice. BMC Neurosci 5:12. CrossRef Medline

Liu S, Shipley MT (2008a) Multiple conductances cooperatively regulate spontaneous bursting in mouse olfactory bulb external tufted cells. J Neurosci 28:1625-1639. CrossRef Medline

Liu S, Shipley MT (2008b) Intrinsic conductances actively shape excitatory and inhibitory postsynaptic responses in olfactory bulb external tufted cells. J Neurosci 28:10311-10322. CrossRef Medline

Liu S, Aungst JL, Puche AC, Shipley MT (2012) Serotonin modulates the population activity profile of olfactory bulb external tufted cells. J Neurophysiol 107:473-483. CrossRef Medline

Maher BJ, Westbrook GL (2008) Co-transmission of dopamine and GABA in periglomerular cells. J Neurophysiol 99:1559-1564. CrossRef Medline

McLean JH, Shipley MT (1988) Postmitotic, postmigrational expression of tyrosine hydroxylase in olfactory bulb dopaminergic neurons. J Neurosci 8:3658-3669. Medline

Najac M, De Saint Jan D, Reguero L, Grandes P, Charpak S (2011) Monosynaptic and polysynaptic feed-forward inputs to mitral cells from olfactory sensory neurons. J Neurosci 31:8722-8729. CrossRef Medline

Nickell WT, Norman AB, Wyatt LM, Shipley MT (1991) Olfactory bulb DA receptors may be located on terminals of the olfactory nerve. Neuroreport 2:9-12. CrossRef Medline

Parrish-Aungst S, Shipley MT, Erdelyi F, Szabo G, Puche AC (2007) Quantitative analysis of neuronal diversity in the mouse olfactory bulb. J Comp Neurol 501:825-836. CrossRef Medline

Pavlis M, Feretti C, Levy A, Gupta N, Linster C (2006) 1-DOPA improves odor discrimination learning in rats. Physiol Behav 87:109-113. CrossRef Medline

Saino-Saito S, Sasaki H, Volpe BT, Kobayashi K, Berlin R, Baker H (2004) Differentiation of the dopaminergic phenotype in the olfactory system of neonatal and adult mice. J Comp Neurol 479:389-398. CrossRef Medline

Schiffmann SN, Desdouits F, Menu R, Greengard P, Vincent JD, Vanderhaeghen JJ, Girault JA (1998) Modulation of the voltage-gated sodium current in rat striatal neurons by DARPP-32, an inhibitor of protein phosphatase. Eur J Neurosci 10:1312-1320. CrossRef Medline

Shao Z, Puche AC, Kiyokage E, Szabo G, Shipley MT (2009) Two GABAergic intraglomerular circuits differentially regulate tonic and phasic pre- 
synaptic inhibition of olfactory nerve terminals. J Neurophysiol 101: 1988-2001. CrossRef Medline

Shao Z, Puche AC, Liu S, Shipley MT (2012) Intraglomerular inhibition shapes the strength and temporal structure of glomerular output. J Neurophysiol 108:782-793. CrossRef Medline

Shirley CH, Coddington EJ, Heyward PM (2010) All-or-none population bursts temporally constrain surround inhibition between mouse olfactory glomeruli. Brain Res Bull 81:406-415. CrossRef Medline

So CH, Verma V, Alijaniaram M, Cheng R, Rashid AJ, O’Dowd BF, George SR (2009) Calcium signaling by dopamine D5 receptor and D5-D2 receptor hetero-oligomers occurs by a mechanism distinct from that for dopamine D1-D2 receptor hetero-oligomers. Mol Pharmacol 75:843-854. CrossRef Medline

Stuber GD, Hnasko TS, Britt JP, Edwards RH, Bonci A (2010) Dopaminergic terminals in the nucleus accumbens but not the dorsal striatum corelease glutamate. J Neurosci 30:8229-8233. CrossRef Medline

Tecuapetla F, Patel JC, Xenias H, English D, Tadros I, Shah F, Berlin J, Deisseroth K, Rice ME, Tepper JM, Koos T (2010) Glutamatergic signaling by mesolimbic dopamine neurons in the nucleus accumbens. J Neurosci 30:7105-7110. CrossRef Medline

Tillerson JL, Caudle WM, Parent JM, Gong C, Schallert T, Miller GW (2006) Olfactory discrimination deficits in mice lacking the dopamine transporter or the D2 dopamine receptor. Behav Brain Res 172:97-105. CrossRef Medline

Tritsch NX, Ding JB, Sabatini BL (2012) Dopaminergic neurons inhibit striatal output through non-canonical release of GABA. Nature 490:262-266. CrossRef Medline

Tsai HC, Zhang F, Adamantidis A, Stuber GD, Bonci A, de Lecea L, Deisseroth $\mathrm{K}$ (2009) Phasic firing in dopaminergic neurons is sufficient for behavioral conditioning. Science 324:1080-1084. CrossRef Medline
Verhagen JV, Wesson DW, Netoff TI, White JA, Wachowiak M (2007) Sniffing controls an adaptive filter of sensory input to the olfactory bulb. Nat Neurosci 10:631-639. CrossRef Medline

Wachowiak M, Cohen LB (1999) Presynaptic inhibition of primary olfactory afferents mediated by different mechanisms in lobster and turtle. J Neurosci 19:8808-8817. Medline

Wachowiak M, Shipley MT (2006) Coding and synaptic processing of sensory information in the glomerular layer of the olfactory bulb. Semin Cell Dev Biol 17:411-423. CrossRef Medline

Wei CJ, Linster C, Cleland TA (2006) Dopamine D(2) receptor activation modulates perceived odor intensity. Behav Neurosci 120:393-400. CrossRef Medline

Wesson DW, Carey RM, Verhagen JV, Wachowiak M (2008) Rapid encoding and perception of novel odors in the rat. PLoS Biol 6:e82. CrossRef Medline

Wu J, Hablitz JJ (2005) Cooperative activation of $\mathrm{D}_{1}$ and $\mathrm{D}_{2}$ dopamine receptors enhances a hyperpolarization-activated inward current in layer I interneurons. J Neurosci 25:6322-6328. CrossRef Medline

Yamaguchi T, Wang HL, Li X, Ng TH, Morales M (2011) Mesocorticolimbic glutamatergic pathway. J Neurosci 31:8476-8490. CrossRef Medline

Yue EL, Cleland TA, Pavlis M, Linster C (2004) Opposing effects of D1 and D2 receptor activation on odor discrimination learning. Behav Neurosci 118:184190. CrossRef Medline

Zhang XF, Hu XT, White FJ (1998) Whole-cell plasticity in cocaine withdrawal: reduced sodium currents in nucleus accumbens neurons. J Neurosci 18:488-498. Medline

Zhang XF, Cooper DC, White FJ (2002) Repeated cocaine treatment decreases whole-cell calcium current in rat nucleus accumbens neurons. J Pharmacol Exp Ther 301:1119-1125. CrossRef Medline 